\title{
BEHIND THE SILVER SCREEN
}

When we take a larger view of a film's "life" from development through exhibition, we find a variety of artists, technicians, and craftspeople in front of and behind the camera. Writers write. Actors, who are costumed and made-up, speak the words and perform the actions described in the script. Art directors and set designers develop the look of the film. The cinematographer decides upon a lighting scheme. Dialogue, sound effects, and music are recorded, mixed, and edited by sound engineers. The images, final sound mix, and special visual effects are assembled by editors to form a final cut. Moviemaking is the product of the efforts of these men and women, yet few film histories focus much on their labor.

Behind the Silver Screen calls attention to the work of filmmaking. When complete, the series will comprise ten volumes, one each on ten significant tasks in front of or behind the camera, on the set or in the postproduction studio. The goal is to examine closely the various collaborative aspects of film production, one at a time and one per volume, and then to offer a chronology that allows the editors and contributors to explore the changes in each of these endeavors during six eras in film history: the silent screen (1895-1927), classical Hollywood (1928-1946), postwar Hollywood (1947-1967), the Auteur Renaissance (1968-1980), the New Hollywood (1981-1999), and the Modern Entertainment 
Marketplace (2000-present). Behind the Silver Screen promises a look at who does what in the making of a movie; it promises a history of filmmaking, not just a history of films.

Jon Lewis, Series Editor

1. ACTING (Claudia Springer, ed.)

2. ANIMATION (Scott Curtis, ed.)

3. CINEMATOGRAPHY (Patrick Keating, ed.)

4. COSTUME, MAKEUP, AND HAIR (Adrienne McLean, ed.)

5. DIRECTING (Virginia Wright Wexman, ed.)

6. EDITING AND SPECIAL VISUAL EFFECTS (Charlie Keil and Kristen Whissel, eds.)

7. PRODUCING (Jon Lewis, ed.)

8. SCREENWRITING (Andrew Horton and Julian Hoxter, eds.)

9. ART DIRECTION AND PRODUCTION DESIGN (Lucy Fischer, ed.)

10. SOUND: DIALOGUE, MUSIC, AND EFFECTS (Kathryn Kalinak, ed.) 



\section{GINEMATOGRAPHY}

\section{Edited by Patrick Keating}

\section{RUTIVERSITY PRESS}

New Brunswick, New Jersey 


\section{Dedicated to two inspiring teachers, David Bordwell and Lea Jacobs}

Library of Congress Cataloging-in-Publication Data

Cinematography / edited by Patrick Keating. pages $\mathrm{cm}$. - (Behind the silver screen ; 3)

Includes bibliographical references and index.

ISBN 978-0-8135-6350-3 (hardcover : alk. paper) - ISBN 978-0-8135-6349-7 (pbk. : alk. paper) - ISBN 978-0-8135-6351-0 (e-book : alk. paper)

1. Cinematography-History. 2. Digital cinematography-History. I. Keating, Patrick, 1970

TR848.C53 2014

$778.53^{\prime} 09-\mathrm{dc} 23$

2013037742

This collection copyright $\odot 2014$ by Rutgers, The State University

Individual chapters copyright $\odot 2014$ in the names of their authors

All rights reserved

No part of this book may be reproduced or utilized in any form or by any means, electronic or mechanical, or by any information storage and retrieval system, without written permission from the publisher. Please contact Rutgers University Press, 106 Somerset Street, New Brunswick, NJ 08901. The only exception to this prohibition is "fair use" as defined by U.S. copyright law.

Visit our website: http://rutgerspress.rutgers.edu Manufactured in the United States of America 